\title{
Protection of Traditional Knowledge in India by Patent: Legal Aspect
}

\author{
Dr.Vishwas Kumar Chouhan \\ Ex.Principal Satpura Law College Chhindwara, Asst.Professor Law ,Govt.State P.G.Law CollegeBhopal
}

\begin{abstract}
Protections of the Traditional Knowledge of the local and indigenous communities seem to be one of the most contentious and complicated issue. The historical development of the protection of intellectual property in the wake of individual private property rights, pushed, the traditional knowledge and the innovative practice based on the it outside the purview of the formal intellectual property protection regime. The need to protect the traditional knowledge captured the attention of the international community only recently but the standard setting was left to the national governments. India an abundant knowledge about the traditional value of various forest products.Natural populations of around $12 \%$ of the 6000 species of potentially medicinal plants are currently estimated to be under threat due to degradation and loss of habitats alongside unsustainable ways of harvesting and lack of cultivation.

Various suggestions have been advanced in India to extend protection to knowledge, innovations and practices. These include:

1. Documentation of TK;

2. Registration and innovation patent system; and

3. Development of a sui generis system.

It is sometimes believed that proper documentation of associated TK could help in checking bio-piracy. Documentation could be a double-edged sword. It is assumed that if the material/ knowledge are documented, it can be made available to patent examiners the world over so that prior art in the case of inventions based on such materials/knowledge are/is readily available to them.
\end{abstract}

\section{Introduction}

Protections of the Traditional Knowledge of the local and indigenous communities seem to be one of the most contentious and complicated issue. The historical development of the protection of intellectual property in the wake of individual private property rights, pushed, the traditional knowledge and the innovative practice based on the it outside the purview of the formal intellectual property protection regime. The new millennium poses serious challenge to the international legal community to set new international legal standard for tacking the problem of intellectual property protection throw open by the technology developments. Traditional Knowledge was treated as Knowledge in the public demeans for free exploitation without showing any respect or concern for the effort taken by the communities to preserve and promote the same.

The new technological developments, particularly in biotechnology, clearly demonstrate the significance and usefulness of traditional knowledge for the development of new product of commercial importance. Traditional knowledge (TK) associated with the biological resources is the knowledge about a country's biodiversity; the applied uses and applications of biological resources and the prevalent practices. TK has direct correlation with the biodiversity of the country. It is an intangible component of the resource itself. TK has the potential of being transformed into commercial opportunity, providing useful leads for development of products and processes. Hence, a share of benefits must accrue to creators and holders of TK .TK valuable in global economy, Important for biotechnology based industries industry and agriculture, Traditional societies depend on it for their food and healthcare needs, Important for conservation and sustainable development of environment and management of biodiversity, Food security of the country is linked to protection of TK .Need to enable tribal communities to harness TK for their economic uplift and growth Fast mobility of tribal societies.

\section{Meaning Of Traditional Knowledge}

Traditional Knowledge (TK), variously referred to as 'traditional knowledge', 'traditional ecological knowledge', 'local knowledge', 'folk knowledge' is knowledge developed by local and indigenous communities over time in response to the needs of their specific local environment. The World Intellectual Property Organization (WIPO) defines traditional knowledge as "indigenous cultural and intellectual property," indigenous heritage," and customary heritage rights .

The need to protect the traditional knowledge captured the attention of the international community only recently but the standard setting was left to the national governments. The absence of the international 
standards, that causes serious negligence for the protection of the traditional knowledge and the benefits of new technology.

\section{Patents And Traditional Knowledge In India}

A little publicized fact about India is that there are around 100 million forest dwellers in India, most of whom belong to tribal communities. The forests provide them with sustenance, providing both timber and nontimber forest produce. In turn, the forest dwellers have over the centuries gathered knowledge from the natural environment around their community.

This community has in one sense been thankfully insulated from the ways of modern man and has carried on the traditions of their ancestors. As a whole, the forests and its dwellers gives to India an abundant knowledge about the traditional value of various forest products. The way intellectual property rights have been designed in modern commerce, traditional knowledge cannot be protected. For instance, traditional knowledge cannot be patented because such knowledge lacks inventive character, because of the inherent lack of novelty.

Traditional knowledge is also often held collectively by communities, rather than by individual owners. This traditional knowledge is information that is transmitted from generation to generation generally within the community or within families within the community in an oral form without any adequate documentation. This has caused traditional knowledge to be undervalued and marginalized. In fact, one of the fears in these communities is that if the knowledge were to be documented it would have been lost to the community by expropriation.

In India, the Forest Act itself acknowledges this fact and provides a framework for documentation of such knowledge and the nature of evidence required for recognition of the rights of these communities in the intellectual property in respect of such knowledge. The provisions of the Biological Diversity Act and Forest Rights Act of 2006 both provide a shield for tribal traditional knowledge, by, one the one hand, respecting and protecting the knowledge of the local communities related to biodiversity and on the other, declaring that the intellectual property rights, in such knowledge belongs primarily to members of the community collectively.

In broad terms, patents can be defined as exclusive rights granted for an invention - either a product or a process - that offers a new technical solution to a specific problem. A patent implies the grant of a "monopoly" to an inventor who has used his knowledge and skills to produce a product or process which is new, involves an inventive step and is capable of industrial application.

The TRIPS Agreement also has some provisions having limited application to the protection of Traditional Knowledge. The obligation to protect geographical indications can be used to protect traditional knowledge if associated with the indication used for production and sale of goods. It is made clear that a given quality, reputation or other characteristics of the goods essentially attributable to its geographical origin are to be considered in identifying the geographical indications for protection. Thus it may be possible for protection through geographical indication the traditional knowledge associated with goods.

Disclosing traditional knowledge which forms part of an invention and of the state of the art or prior art will promote the progress of science by creating an incentive for the maintenance of traditional knowledge systems . This will happen by traditional knowledge being widely and universally accepted within "western" or "modern" innovation protection systems and becoming a reference point within the regular operations of the international patent system.

\section{Traditional Knowledge In Danger}

The national knowledge commission India recommended to protect traditional knowledge and said Establish goals for conservation of natural resources: Natural populations of around $12 \%$ of the 6000 species of potentially medicinal plants are currently estimated to be under threat due to degradation and loss of habitats alongside unsustainable ways of harvesting and lack of cultivation. The problem of growing scarcity also leads to the danger of more counterfeit material being marketed. It is therefore necessary to support conservation and sustainable harvesting efforts in the forestry sector and cultivation in the agricultural sector. Direct support for conservation and cultivation as well as indirect methods through incentive policies should be pursued for nurturing these plant resources. The wild gene pool of India's medicinal plants should be secured, via establishment of a nation wide network of 300 'Forest Gene Banks' across the 10 bio-geographic regions of the country.

A. Support non-Government and corporate initiatives for promotion of THS: The non-government and private sector have played an important role in building the public image of traditional health sciences. Nongovernmental research and education institutions, NGOs and corporate with a global vision must be strategically supported in the interest of enhancing national and international awareness of India's rich health system heritage.

B. Promote international cooperation: International cooperation in exploration of traditional health systems 
must be given a big boost through substantial initiatives like strategic research collaborations with reputed research centres and establishing wellness centers in countries that offer promising market opportunities.

EXIM bank of India must be supported to work with industry to open world markets for these products and services.

C. Support primary healthcare in rural areas: With $70 \%$ of Indian population relying on traditional medicine for primary health care in the absence of adequate state primary health care, it becomes necessary to establish evidence-based guidelines for this informal-sector usage. A nation-wide network of Home Herbal Garden and Community Herbal Gardens (CHG) can be created to support the primary health care needs of rural communities for those plants and medications established as efficacious by evidence-based research.

D. Create a major re-branding exercise of Indian traditional medicine: Better branding of Indian traditional medicines proven to be effective in well-designed clinical trials can increase safe and effective healthcare options. Such proven medications should be integrated with the national healthcare system. Such evidencebased, well-validated and uniquely Indian holistic healthcare system combinations must be marketed extensively globally.

In order to achieve these goals as rapidly and efficiently as possible, the Government of India may consider establishing a National Mission on Traditional Health Knowledge (NMTHK), which would take up these tasks in an organized way. It should be a relatively small body in terms of its own infrastructure with powers to enable it to recommend targeted funding in identified areas. It should support initiatives at many different levels, including state and local levels, and coordinate with Ministries of Health, Science \& Technology, Forestry, Agriculture, and Commerce as well as with the NGOs and private sector. The Mission leader must be a person with high public credibility, have extensive knowledge and experience in the field with established managerial capabilities and experience of dealing with all the concerned stakeholders.

The above mention facts shows importance of protection of Traditional Knowledge in India and indicate Traditional Knowledge is in Danger, some other reasons are following -

ENCROACHMENT, BI-PROSPECTING AND BIO-PIRACY: One of the biggest threats to biodiversity and related traditional knowledge is ever-increasingly bioprospecting activities on behalf of enthobotonists, pharmaceutical companies and others who wish to profit from the rich biodiversity and traditional knowledge in indigenous territories.

Current legal systems are inadequate, allowing for the biopiracy of biodiversity and traditional knowledge. "Legislation is required and it is required yesterday," says Noiwazi Gcaba, a South African patent attorney.

DEVOLUTION: As demand for commercialization of biodiversity and traditional knowledge increases at a rapid pace and as the world globalizes, develops and modernizes, indigenous societies are being encroached upon faster than traditional knowledge can be protected. Their cultures and knowledge are being lost. In many parts of the world, the very existence of indigenous societies is under threat

\section{Inadequacy Of Legal System That Address Traditional Knowledge}

This point is divided into two major sections:-

\section{General issues relating to the protection of traditional knowledge.}

Devolution, encroachment, the bio prospecting rush, lack of appropriate legal systems and a clash of systems all make traditional knowledge highly vulnerable to Biopiracy. Several traditional plants and related knowledge in Asia, specifically India, have also been allegedly falsely patented by the US patent office, including: Neem', Haldli', pepper, Harar', Mustard, Basmati rice, Ginger, Castor, 'Jaramla', 'Karela' and 'Jamun'. The African continent has too been plagued by biopiracy - with the case of West Africa's sweet genes and one of the most recent cases involving "Hoodia" still unresolved. Some cases have been resolved but clearly demonstrate the problems with the intellectual property system.

Traditional knowledge is generally associated with biological resources and is invariably an intangible component of such a biological resource. Traditional knowledge has the potential of being translated into commercial benefits by providing leads/clues for development of useful practices and processes for the benefit of mankind. The valuable leads/clues provided by TK save time, money and investment of modern biotech and other industries into any research and product development. Reasonably, we can say that a share of such benefits should accrue to the creators and/or holders of such Traditional Knowledge. Some countries have specific legislation protecting this kind of knowledge while some other countries feel their existing IPR regime protects such knowledge. As of now, India does not have a specific sui generis legislation to protect such TK and folklore but is in the process of developing such legislation. 
In the recent past, there have been several cases of bio-piracy of TK from India. First it was the patent on wound-healing properties of haldi (turmeric); now patents have been obtained in other countries on hypoglycaemic properties of karela (bitter gourd), brinjal, etc. An important criticism in this context relates to foreigners obtaining patents based on Indian biological materials without acknowledging the source of their Knowledge or sharing the benefits.

There is also the view that the TRIPS Agreement is aiding the exploitation of biodiversity by privatizing biodiversity expressed in life forms and knowledge

\section{A. Neem:}

A tree legendary to India has been used as a biopesticide and medicine in India for century's.. Ancient Indian Ayurvedic texts have described the Neem tree and it's medicinal healing properties as far back as 5000BC The Europion patent office (EPO) revoke in its entirety patent number 436257 which had been granted to the united state of American and the multinational corporation W.R. Grace for a fungicide derived from seed of the Neem tree. Despite Neem's ancient tradition, over 12 US patents were recently taken out Neem-based emulsions and solutions.

\section{B. Turmeric}

In 1993, the US PTO granted the University of Mississippi Medical Center patent rights over a "healing a wound by administering turmeric to a patient afflicted with a wound." But again, Turmeric has been used for centuries in India. Indians grow up with a constant awareness of turmeric the tuber when dried keeps practically forever. The patent was eventually cancelled in 1998 after reexamination proceedings. But revealed to India and to indigenous societies around the world, again, how easy it was to falsely patent centuries-old traditional knowledge.

\section{Basmati Rice}

In 1997, the US patent office granted a patent in September 1997 to 'Rice Tec' for a strain of Basmati rice, an aromatic rice grown in India and Pakistan for centuries. This case has not yet been resolved, but the Indian Government is actively pursuing the case, stating that it violates both TRIPS and the CBD. According the 'South Asia Commission on Economic and Social Policy, Rice Tec's patent also violated the CBD in not recognizing the sovereign rights of India and Pakistan over Basmati rice. In basmati case demonstrates the problem as illustrated in TRIPS that patents are granted to biotechnological processes. Thus, even though basmati rice has been in South Asia for centuries, Rice Tec just altered it slightly through crossing with a Western strain of grain, and successfully claimed it was its own.

\section{Maca}

In 2001 after the Viagra craze, two US companies patented extracts of the Andean plant, "Maca" which has traditionally been used to enhance fertility and sexual function. The patents were granted on the basis of "unlocking maca's chemical secrets" through advanced processes. .It has become clear, though narrating these few cases that IP laws cannot or are not being effectively applied to prevent the biopiracy of traditional knowledge. Traditional knowledge is being treated as a free input into research and commercial product development. When patents are falsely granted, equitable benefit sharing is not taking place either, while indigenous peoples remain subject to biopiracy and become ever more marginalized in the process.

Recently amended patent law of ours contains provisions for mandatory disclosure of source and geographical origin of the biological material used in the invention while applying for patents in India. Provisions have also been incorporated to include non-disclosure or wrongful disclosure of the same as grounds for opposition and for revocation of the patents, if granted. To protect Traditional knowledge from being patented, provisions have also been incorporated in the law to include anticipation of invention by available local knowledge including oral knowledge, as one of the grounds for opposition as also for revocation of patent. In order to further strengthen these provisions, a new provision has been added to exclude innovations which are basically traditional or aggregation or duplication of known properties of traditionally known component or components from being patented.

\section{Granting of patents in respect of traditional knowledge:}

Concern that has been expressed in the discussion in the council for TRIPS is about the grant of patents or other IPRs covering traditional knowledge to persons other then the indigenous peoples or community who have originated the knowledge and legitimately control it. Several patents have been cited as ex. including in regard to turmeric, Neem and Athabasca vine The view has been expressed that the granting to patents on traditional knowledge already in the public domain or without the content of indigenous peoples and local communities amount to unauthorized appropriation of the knowledge It has bee said that this occur particularly 
in the case where members do not appropriate definition of the criteria for penetrability or appropriate procedure.

Two area it has been said that the patent system is not working well enough in connection with the granting of patent covering traditional knowledge have been referred to "Definition of prior art" used to determine weather a claimed invitation meets the novelty stranded for patentability. The second concern the "adequacy of the information on prior art" available to patent examiners.

\section{Consent and benefit sharing:}

Traditional knowledge is being used without the authorization of the indigenous peoples or communities who have originated and legitimately control it and without proper sharing of the benefit that occurs from such use. Use of the existing system IPR: -It has been suggest theta starting point should be explore possibility for making more effective use of the exciting IPR system for protecting the traditional knowledge of indigenous peoples and local communities.

\section{CONTRACT:}

It has been suggest that the beat way of dressing this concern would be through system based on bilateral contract between holder of traditional knowledge and persons or companies wishing to access and use the knowledge.

DISCLOSURE REQUIREMENT: It has been suggest that applicant for patent for indentations that used traditional knowledge associated with genetic resources should be required to disclose the course. Or the origin of the source of the traditional knowledge in their patent applications.

SUI GENERIES SYSTEM OF PROTECTION:- It has been suggest that only a system of protection of traditional knowledge which provides proprietary rights can insure that market forces will be operate to generate fairness and equity. The suggestions concerning contracts and disclosure, which have also been made in regarded to genetic material used in invention that are the subjects of patent application, are discuss in more detail in the secretariat's revised summery note on the relationship between the TRIPS agreement and convention on biological diversity.

The Indian legislation for the Protection of Plant Varieties and Farmers' Rights Act 2001 also acknowledge that the conservation, exploration, collection, characterization, evaluation of plant genetic resources for food and agriculture are essential to meet the goals of national food and nutritional security as also for sustainable development of agriculture for the present and future generations. It also acknowledges that the plant genetic resources for food and agriculture are the raw material indispensable for crop genetic improvement. The concept of effective benefit sharing arrangement between the provider and the recipient of the plant genetic resources forms an integral part of our Act. The protection provided to a plant variety bred by a breeder can be cancelled if there is an omission or wrongful disclosure of such information.

\section{Strategies To Increase Protection Of Traditional Knowledge :}

International Efforts: Indian Traditional Knowledge available to the USPTO - Patent examiners of the United States Patent and Trademark Office (USPTO) are now able to access the Database of Traditional Knowledge thanks to the Indian Government according its permission in November 2009. India's Council of Scientific and Industrial Research, and the Department of Ayurveda, Yoga and Naturopathy, Unani, Siddha and Homeopathy was credited with the development of the Traditional Knowledge Digital Library (TKDL), which is a 30 million page searchable database of traditional knowledge translated from numerous languages such as Hindi, Sanskrit, Arabic, Persian, Urdu and Tamil into English, Japanese, French, German and Spanish. The EPO was allowed the use of the TKDL in February 2009.

\section{MOU between USPTO and India on Bilateral Intellectual Property Rights Cooperation -}

The Indian Department of Industrial Policy and Promotion (DIPP) and USPTO announced on the 23rd of November 2009 that they have entered into a MOU on comprehensive bilateral cooperation for IPR protection and enforcement. Under the terms of the MOU, the USPTO and DIPP will cooperate on a range of IPR issues, focusing on capacity building, human resource development, and raising public awareness of the importance of IPR.Secretary of the DIPP, Mr. Ajay Shankar said: "Our vision is to transform our IP system into a world class organization by adopting transparent, automated and user-friendly procedures. The MOU that we are signing today would help strengthen our capacity to achieve this objective."

There are several other international legal platforms and instruments that currently address intellectual property protection as it relates to traditional knowledge. Some of the most prominent include 
The UN Draft Declaration on Rights of Indigenous Peoples:

This UN Draft Declaration, in Article 29, specifically states that "Indigenous peoples are entitled to the recognition of the full ownership, control and protection of their cultural and intellectual property. They have the right to special measures to control, develop and protect their sciences, technologies and cultural manifestations, including human and other genetic resources, seeds, medicines, knowledge of the properties of fauna and flora, oral traditions, literatures, designs and visual and performing arts."

Global Guidelines: A recent positive initiative is the drafting of a set of corporate guidelines for businesses that want to use native plants and traditional knowledge from indigenous communities to make commercial drugs. In April 2002 in The Hague, delegates of the UN Biodiversity Congress from 166 countries negotiated and adopted global guidelines during a two- week long U.N. sponsored CBD conference that was designed to encourage pharmaceutical companies to make responsible agreements with countries whose resources they use

Regional Initiatives: The Cancun Declaration \& Cusco Declaration on Access to Genetic Resources. Traditional Knowledge and Intellectual Property Rights: In February 2002, Environmental Ministers from 12 countries met inCancun, Mexico met to discuss issues related to biodiversity in their countries, identifying a need to establish terms governing the granting of patents. At the WSSD in Johannesburg this past August, their group was established as a permanent negotiating body to address these issues."

It has also been suggested that a requirement on patent applications to disclose in their applications any traditional knowledge used in the invention in question could help in the assessment of novelty and also assist countries with possible claims to examine the application and oppose the patent in time.

The Geographical Indication of Goods (Registration and Protection) Act, 1999 passed by Parliament is another step taken by India. The Act primarily intends to protect the valuable geographical indications of our country. The protection under the Act is available only to the geographical indication registered under the Act and to the authorized users. The Act permits any association of persons or producers or any organization or authority established by law representing the interest of the producers of goods to register a geographical indication. It may be possible to argue that the holders of the traditional knowledge in goods produced and sold using geographical indication can register and protect their traditional knowledge under this law.

\section{Consequences of efforts:}

Time lines for patent processing has been considerably reduced.It has been made possible to obtain a patent in 8 months as opposed to 6-8 years. Backlog of over 44,000 patent applications have been liquidated in approximately three years.

\section{Concerns-}

Patent infringements - no injunctive relief granted, Pharmaceutical patents - external pressures, No specialised courtsTrials are delayed ,No culture of damages Actual costs.

\section{Judicial Pronouncements}

\section{J. Mitra Company Pvt. Ltd. vs. Span Diagnostics- CS (OS) No. 2020/2006 - Judgment dated} 22.02.2008.-

Hepatitis C diagnostic kit ...Judgement delivered by Hon'ble Mr. Justice Sanjay Kishan Kaul of the Delhi High Court: Sufficient documents were filed showing the research conducted by J. Mitra. Whereas, the defendant showed no research or development towards its infringing product. Relevance of PCT Report - not binding while evaluating Obviousness \& Inventive step-The Patent is not hit by prior art, No credible challenge to the validity of the patent , Injunction granted ,In Division Bench, for disposal of existing stocks - The Court directed deposit of $30 \%$ of proceeds., Trial is continuing.

\section{Bayer vs. Union of India (2009 Patent Linkage}

No Linkage between marketing approval and patent infringement, Writ dismissed with costs ,Division Bench held that it is a matter of governmental policy ,Pending before Supreme Court

\section{F. Hoffmann-L.A. Roche Ltd. and Anr. vs. Cipla Ltd. (2008) ERLOTINIB HYDROCHLORIDE--}

Justice Ravindra Bhat held that "Credible Challenge" is raised ,Price difference is important to decide balance of convenience ,No injunction - accounts be filed ,Division Bench found concealment by Roche ,Supreme Court expedited trial

TRIAL ABOUT TO CONCLUDE--Fastest Patent trial in less than 2.5 years since filing of suit. 
Protection of Traditional Knowledge in India by Patent: Legal Aspect

4. Span Diagnostics Vs. J.Mitra 2008(37) PTC 56 - Justice Nandrajog-Whether appeal was maintainable in view against pre-grant opposition

18 month vacuum ,IPAB was yet to be notified, Appeal held maintainable - transferred to IPAB

5. J.Mitra Vs. Controller of Patents- Supreme Court slightly modified - Justice Kapadia's judgement:- No appeal lies against pre-grant order , only in view of unusual circumstances appeal to be entertained ,To be heard by High Court

Supreme Court slightly modified - Justice Kapadia's judgement:- No appeal lies against pre-grant order ,only in view of unusual circumstances appeal to be entertained, To be heard by High Court - Procedural ironing out by Courts ,Justice Murlidhar Held Pre-Grant ,Oppn Rejected - no appeal or writ - go for Post-Grant ,Patent rejected - appeal to IPAB

6. Snehlata C. Gupte vs. Union of (15th July'2010)-- SERIAL OPPOSITIONS

Pre-Grant by Party A Decision in opposition on X date - Controller orders for grant Second oppn filed next day ,Grant and sealing yet to take place ,Pre-grant can be filed anytime before grant ,Court held SERIAL OPPOSITIONS IMPERMISSIBLE

STATISTICS OF IPR CASES FROM 2007 ONWORDS AS 0N 24/04/2010 IN INDIA

\begin{tabular}{|l|l|l|l|l|}
\hline Year & $\begin{array}{l}\text { Pendency as of } \\
\text { 1st January }\end{array}$ & Institutions & Disposals & $\begin{array}{l}\text { Pendency as on } \\
\text { 31st December }\end{array}$ \\
\hline $\mathbf{2 0 0 7}$ & 1311 & 548 & 488 & 1371 \\
\hline $\mathbf{2 0 0 8}$ & 1371 & 409 & 450 & 1330 \\
\hline $\mathbf{2 0 0 9}$ & 1330 & 561 & 499 & 1392 \\
\hline $\begin{array}{l}\mathbf{2 0 1 0} \\
\text { (Upto } \\
\mathbf{2 0 1 0}\end{array}$ & 1392 & 154 & 133 & $\begin{array}{l}1413 \\
\text { (Upto } \quad 24.04 . \\
\text { 24.04. }\end{array}$ \\
\hline
\end{tabular}

TOTAL PENDENCY AS ON 24.04.2010 --- --- 1413

(Source: Justice Bhat - APAA World IP Day Seminar 2010 )

\section{PATENT CASES}

Rise in patent litigation - reported cases nos. -2005 - 3,2006- $\quad 4$, 2007- 9 ,2008$22,2010-12$ (till July 2010)

\section{Conclusion:}

Suggestion for Improve Indian Patent act for Traditional Knowledge

In responsible, it has been said that:

- The criteria for patentability are properly applied; the granting of erroneous patents would be avoided

- Under the patent law of many member, prior art comprises not only earlier disclosures in writing but also what is early publicly know or used any where in the world.

In response it has been said that, even if the national laws applicable do not allow patents on invention based on traditional knowledge, patents in other regimes that allow such patents reduce the economic value of the knowledge of local community and may constrain the development and use of their knowledge in the marketplace or may facilitate otherwise of exploitation of their knowledge with out any rewards to them. It has been suggest that the development of database on traditional knowledge would help patent examiners discover relevant prior art so as to improve examination of patent application and prevent the grant of patents for subject matter that should not be patentable.. Database would also help potential licensees in terms of searching for knowledge, innovations and parties'

Various suggestions have been advanced in India to extend protection to knowledge, innovations and practices. These include:

(i) Documentation of TK;

(ii) Registration and innovation patent system; and

(iii) Development of a sui generis system.

It is sometimes believed that proper documentation of associated TK could help in checking bio-piracy. Documentation could be a double-edged sword. It is assumed that if the material/ knowledge are documented, it can be made available to patent examiners the world over so that prior art in the case of inventions based on such materials/knowledge are/is readily available to them. It is also hoped that such documentation would facilitate tracing of indigenous communities with whom benefits of commercialization of such materials/knowledge has to be shared.

Some specific suggestions: 
1. Access to these databases for patent authorities and relent judicial authorities could be facilitated through the establishment of an international gateway for traditional knowledge, which would electronically link this data based.

2. At least minimum harmonization of the structure and content for these data based should be achieve

3. Data based should be reachable over the Internet.

4. To the extent that traditional knowledge which already recorded in databased and print media, it is important to insure that patent examiners are made familiar with this resources.

5. Databased should only disclose traditional knowledge already in the public domain or traditional knowledge for which prior inform consent has been obtained.

6. Access these data based should not involve costly or burdensome procedures.

In this regard, concerns have been expressed about the following:

1. In this responsibilities for bearing cost of maintaining these database.

2. While serving as repository of information, database cannot be completely exhaustive as they may not contain knowledge held by local communities in oral form or knowledge that is continuously evolving through informal innovation within a community.

3. While database may help forestall the grant of inappropriate patents, they cannot address the problem of the non-accrual to the holders of traditional knowledge of economic benefits resulting from the use of knowledge.

4. Reference to database by patent examiner would be voluntary and patent examiners in member countries would have no obligation to consider this information in their prior art searches. Obligations, guidelines or recommendations should be established to improve and substantial tighten up search systems in respect of information that is relevant to traditional knowledge so as to evaluate novelty and inventiveness.

Documentation of traditional knowledge is also acknowledge as a means of giving due recognition to the traditional knowledge holders. This particular aspect of documenting formulations in the Ayurvedic system of medicine in India in the shape of traditional knowledge Digital Library (TKDL) is already on and we appreciate the efforts of WIPO to arrange for a presentation in this regard as also on the topic of Health Heritage Data Base for the benefit of the members attending the last Intergovernmental Committee meeting in Geneva in June 2002. The scope of the TKDL work relates to the transcription of 35,000 formulations used in Ayurvedic system of medicines. These details are being converted into Patent Application Format and will include description, method of preparation, claim and the usage of the bibliography.

Documentation of TK is one means of giving recognition to knowledge holders. But mere documentation may not enable sharing of benefits arising out of the use of such knowledge, unless it is backed by some kind of mechanisms for protecting the knowledge. This necessitates the need for extending some kind of protection to TK. Documentation of TK may only serve a defensive purpose, namely that of preventing the patenting of this knowledge in the form in which it exists. Documentation per se, however, will not facilitate benefit sharing with the holders of TK.

\section{References}

[1] WIPO “Intellectual Property Needs \& Expectation of Traditional Knowledge Holders” WIPO Report on Fact- Finding Missions on Intellectual Property \& Traditional Knowledge (1998-1999) pg.25. Id at 25. [2] WIPO "Intellectual Property Needs \& Expectation of Traditional Knowledge Holders" $\quad$ WIPO Report on Fact- Finding Missions
on Intellectual Property \& Traditional Knowledge (1998- 1999) pg.25.

[3] Biodiversity, 13ioteclmology and the Protection of Traditional Knowledge," Washington University in St. Louis School of Law Conference, April 4-6, 2003. www.wto.org/english/tratop_e/trips_e/t_agm0_e.htm

[4] Balick, Michael, "Traditional Kiowledge: Lessons from the Past, Lessons for the Future," p. 3, paper presented at conference,"Biodiversity, Biotechnology and the Protection of Traditional Knowledge," Washington University in St. Louis School of Law, Conference, April 4-6, 2003.

[5] Shiva, Vandana, "The US Patent System Legalizes Theft and Biopiracy," THE HINDU, July 28 1999.www.wipo.int/documents/en/meetings/2002/igc/doc/grtkfic3_14.docTestsite3.nic.in/trips_agreement_and_convention.html.

[6] Shiva, Vandana, "Indigenous Knowledge and IPRs," Biopkacy: The Plunder of NatHre and Knowledge, South End Press, Boston, p. 69 . "About Neem," at http:/fwww.neem.com.auJabout.html

[7] Walker, Simon "The TRIPS Agreement, Sustainable Development and the Public Interest A Discussion paper” INCU Law and Policy paper no. 41, IUNCE \& CILE, 2001, PG.36.

[8] Gollin, Michael, "New Rules for Natural Products," Sep. 1999, Vol. 17 \&9, pg 921-922.

[9] Devraj, Ranjit, " US Corporate Biopirates Still Staking Claim on Basmati Rise," Common Dreams New Delhi.

[10] Higher Education and Research Opportunities in the UK (HERO), "Knowledge Grabbers Pay Nothing," available at: ttp:f/www.hero.ac.ukiresearcblknowledge grabbers pay no4305.cfm ${ }^{3}$ India, IP/CIW/198, IP/CIM/48, paras, 5759. www.wipo.int/edocs/mdocs/tk/en/wipo_gr_im_ge_04/ipgr_gopalakrishnan.pdf. 14. Brazil, IP/C/W/228.

[11] Peru,IP/CIW/447;Indja, IP/C/M130,para. 170 India, IP/C/M139, Para. 122, 1P1C128, Para. 126; Kenya, IP/C/M/28, Para. 141; Peru, 1P/C/W/447 AUSTRALIA, IP/C/W/310;EC,IP/C/W/383; Japan, IP/C/M/29,para 157 United Sate, IP/CIW/434,IP/C/W/393,IP/CIW/341,IP/CIW/257 Switzerland, IP/C/W/433,IP/C/W/423, IP/CIWI400IRev.1 EC, IPIC/383, 1P/C/M/44 Para. 29, IPIC/W42 Para 107. ,IP/C/M/37fadd. 1 Para. $228^{1}$ www.wto.org/english/tratop_e/TRIPS_e/ipcw369r1.doc

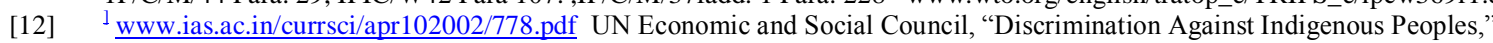
Report of Working Group on Indigenous Populations in its 11th Session, E/CN.4/Sub.2/1993/29/Annex 1.23 August 1993, http;//www.cswis.org/fwdp/drft9329.html

[13] United Nations Convention on Biological Diversity, available at www.biodiv.org. Bravo, Elizabeth, "The Biodiversity Convention: 10 years On," October 2002, available at:

[14] http://www.grain.org/seedling/seed-02-10-4-eri.cfm. www.patentoffice.nic.in/ipr/gi/geo_ind.html Justice Bhat - APAA World IP Day Seminar 2010) 